\title{
Način korištenja ekoloških površina na razini EU i u odabranim državama članicama
}

\section{Sažetak}

Ekološka poljoprivreda je rastući sektor u Europskoj uniji (EU). Cilj rada je bio ustanoviti načine korištenja ekoloških površina na razini Europske unije i u odabranim državama članicama u razdoblju od 2012. - 2017. godine. Ekološke površine su se na razini Europske unije u promatranom razdoblju povećale za 25\%. Najveće povećanje su zabilježile Bugarska (249\%) i Hrvatska (202\%), a slijede Francuska (69,21\%), Italija (63,49\%), Mađarska (52,89\%) i Litva (49,57\%). Obzirom na način korištenja u Europskoj uniji u 2017. godini ima podjednako obradivih površina (44,5\%) i trajnih travnjaka (44,4\%) dok višegodišnji nasadi zauzimaju 11,1\% površina. Kada se prati kretanje pojedinih načina korištenja zemljišta u razdoblju od 2013. do 2017. godine, najveći rast bilježe obradive površine (29\%), slijede trajni travnjaci (22\%) i višegodišnji nasadi (19\%).

Ključne riječi: ekološka poljoprivreda, EU, način korištenja zemljišta

\section{Uvod}

Ekološka poljoprivreda je perspektivni način uzgoja koji ima pozitivan utjecaj na okoliš, a ujedno se bavi i raznim ekonomskim i socijalnim aspektima, doprinoseći održivom razvoju ruralnih područja kao i zaštiti svih komponenti okoliša (Palšováa i sur., 2014). Toje rastući sektor, kako u svijetu, Europskoj uniji (EU), tako i u Hrvatskoj. Površine pod ekološkom poljoprivredom na području EU zauzimaju 7,2\%, a u Hrvatskoj 6,1\% ukupno korištenih poljoprivrednih površina (Willer i Lernoud, 2019). Unatoč povećanju ekoloških poljoprivrednih površina, proizvodnja nije dovoljna za zadovoljavanje rastuće potražnje za tim proizvodima u Europi (Willer i sur., 2019).

Struktura poljoprivrede, a tako i način korištenja površina u ekološkoj poljoprivredi, u državama članicama Europske unije i u svijetu razlikuje se ovisno o geologiji, topografiji, klimi i prirodnim resursima, kao i raznolikosti regionalnih aktivnosti, infrastrukture i društvenih običaja (Pilipavičius i Grigaliūnas, 2014). Na svjetskoj razini u ekološkom uzgoju imamo najviše trajnih travnjaka (69\%), slijede obradive površine (17\%), najmanje je trajnih nasada $(7 \%)$ dok za $7 \%$ površina nema podataka o načinu korištenja. Kada govorimo o geografskoj raspodjeli načina korištenja, najviše trajnih travnjaka je smješteno u Oceaniji, a obradivih površina i trajnih nasada u Europi (Lernoud i Willer, 2019).

Ekološka se poljoprivreda u Hrvatskoj počinje ozbiljnije razvijati nakon uspostave zakonodavnog okvira 2001. godine. Nakon uspostave zakonodavnog okvira točnije 2002. godine, prvi se ekološki proizvođači upisuju u Upisnik ekoloških proizvođača poljoprivrednih i prehrambenih proizvoda pri Ministarstvu poljoprivrede (MP) a iste godine je dobiven i prvi hrvatski certifikat u ekološkoj poljoprivredi (Zrakić i sur., 2017). Danas u Hrvatskoj imamo 5.742 subjekta koji se bave ekološkom poljoprivredom. Najveći broj novoregistriranih je bio u 2015. godini, njih čak 965 (Ministarstvo poljoprivrede, 2019.).

Cilj rada je ustanoviti načine korištenja ekoloških površina na razini Europske unije i u odabranim državama članicama u razdoblju od 2012. - 2017. godine. 


\section{Materijali i metode}

U radu je korištena deskriptivna analiza sekundarnih izvora podataka. Analiza načina korištenja površina pod ekološkom poljoprivredom izrađena je na razini EU 28 i za šest država članica koje su u promatranom razdoblju zabilježile najveći rast površina pod ekološkom poljoprivredom: Bugarsku, Hrvatsku, Francusku, Mađarsku, Italiju i Litvu' ${ }^{1}$. Analiza je rađena za razdoblje od 2012. do 2017. godine zbog dostupnosti podataka u EUROSTAT-u na državnoj razini za članice EU.

Kao ekološke površine promatrane su površine koje su u prijelaznom razdoblju (konverziji) s konvencionalne na ekološku kao i u potpunosti konvertirane ekološke površine.

\section{Rezultati i rasprava}

Na razini EU 28 u razdoblju od 2012. do 2017. godine bilježi se povećanje površina pod ekološkom poljoprivredom za $25 \%$. Od država koje su u navedenom razdoblju zabilježile najveće povećanje vodeća je Bugarska (249\%), a slijede redom: Hrvatska (203\%), Francuska (69,21\%), Italija $(63,49 \%)$, Mađarska $(52,89 \%)$ i Litva $(49,57 \%)$. Čak četiri EU članice u navedenom razdoblju bilježe smanjenje površina pod ekološkom poljoprivredom, a to su: Poljska $(-24,49 \%)$, Ujedinjeno Kraljevstvo (-15,64\%), Grčka (-11,34\%) i Rumunjska (-10,33\%) (grafikon 1).

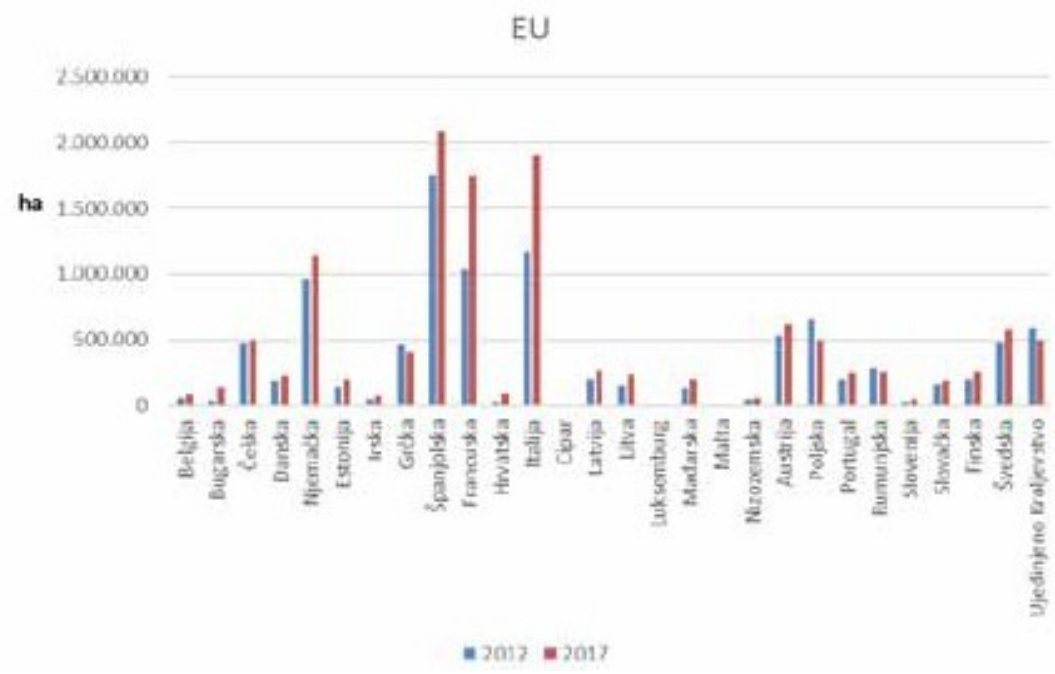

Grafikon 1. Površine pod ekološkom poljoprivredom u državama članicama EU 2012. i 2017. godine./

Graph 1. Area under organic farming in the EU member states in 2012 and 2017

Izvor: Izrada autora prema podatcima EUROSTAT-a/Source: Prepared by the author according to EUROSTAT data

Obzirom na način korištenja u EU 28 u 2017. godini ima podjednako obradivih površina $(44,5 \%)$ i trajnih travnjaka $(44,4 \%)$ dok višegodišnji nasadi zauzimaju $11,1 \%$ površina. Kada se prati kretanje pojedinih načina korištenja zemljišta u razdoblju od 2013. do 2017. godine, najveće povećanje bilježe obradive površine (29\%), slijede trajni travnjaci (22\%) i višegodišnji nasadi (19\%) (grafikon 2). 


\section{EU 28}

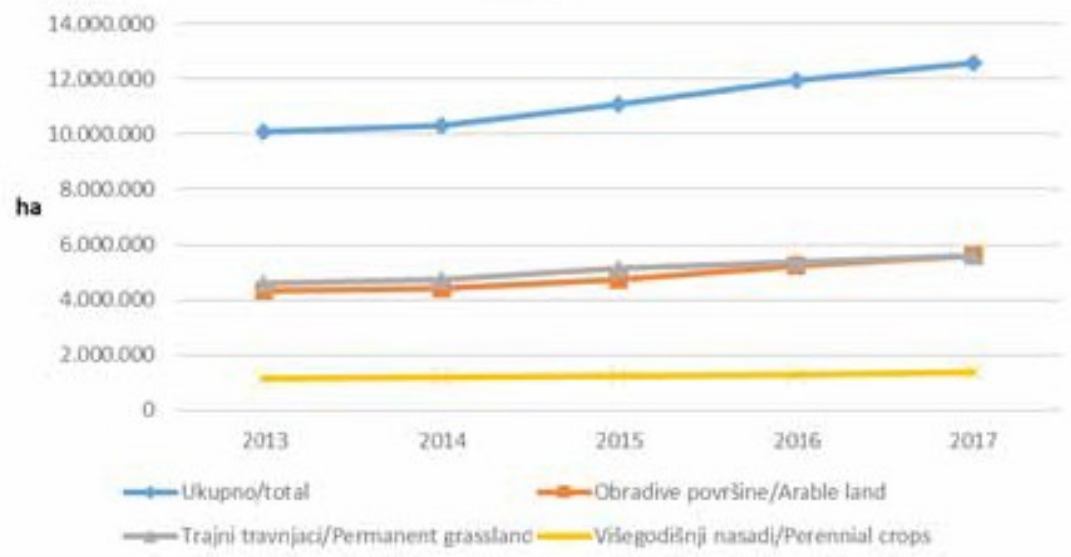

Grafikon 2. Način korištenja površina pod ekološkom poljoprivredom u EU 28 u razdoblju od 2013. do 2017. godine./

Graph 2. The way of use areas under organic farming in the EU 28 in the period from 2013 to 2017 Izvor: Izrada autora prema podatcima EUROSTAT-a/Source: Prepared by the author according to EUROSTAT data

U Bugarskoj, državi koja u EU bilježi najveće povećanje površina pod ekološkom poljoprivredom, u promatranom razdoblju postoje znatna kolebanja: rast između 2012. i 2013., pad od 2013. do 2014., zatim rast od 2014. do 2016. i znatan pad između 2016. i 2017. godine. Između 2016. i 2017. godine rastu samo površine pod trajnim travnjacima i to neznatno, dok je značajan pad obradivih površina, čak $-25,36 \%$.

\section{Bugarska/Bulgaria}

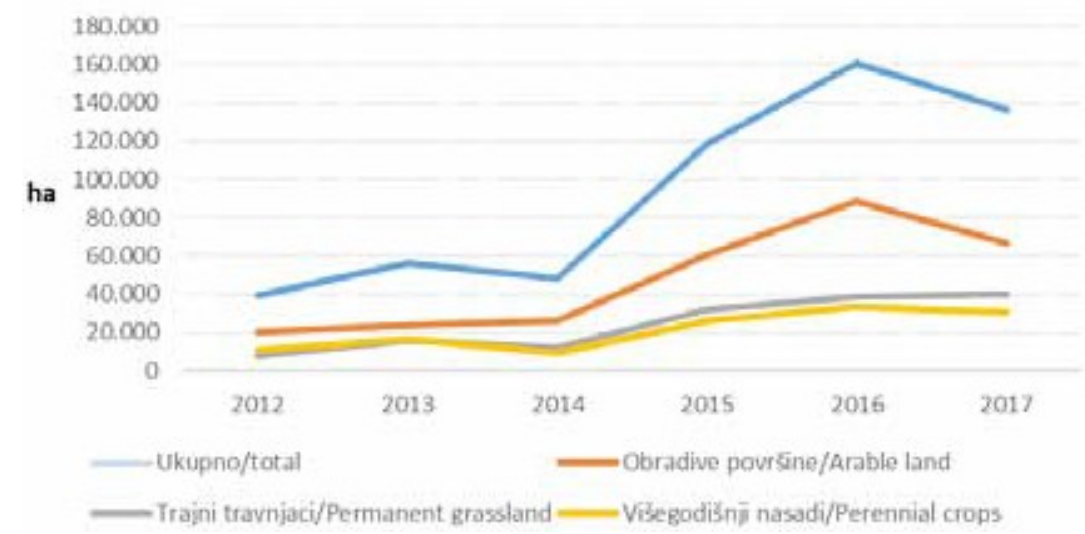

Grafikon 3. Površine pod ekološkom poljoprivredom u Bugarskoj prema načinu korištenja/

Graph 3. Area under organic farming in Bulgaria according to the way of use

Izvor: Izrada autora prema podatcima EUROSTAT-a/Source: Prepared by the author according to EUROSTAT data 
Jancsovszka-Puskas (2015) navodi kako je u Bugarskoj glavni motiv za bavljenje ekološkom poljoprivredom primanje potpora, a ne privlačnost koncepta ili pak odgovor na potražnju za tim proizvodima. Također navodi kako je potpora u trogodišnjem prijelaznom razdoblju poljoprivrednicima vrlo privlačna, no nema garancije da će se postići konverzija iz konvencionalne u ekološku poljoprivredu. Navedeno je vrlo vjerojatno i razlog naglog pada površina u 2017. godini. Naime, poljoprivrednici koji su krenuli s konverzijom 2014. godine (nagli rast površina) po isteku trogodišnjeg razdoblja konverzije nisu prešli u ekološke poljoprivrednike. Tome u prilog ide i činjenica da su kolebanja u ukupnim površinama (u potpunosti konvertirano i u konverziji) uzrokovana kolebanjima površina u konverziji s konvencionalne na ekološku poljoprivredu (grafikon 4).

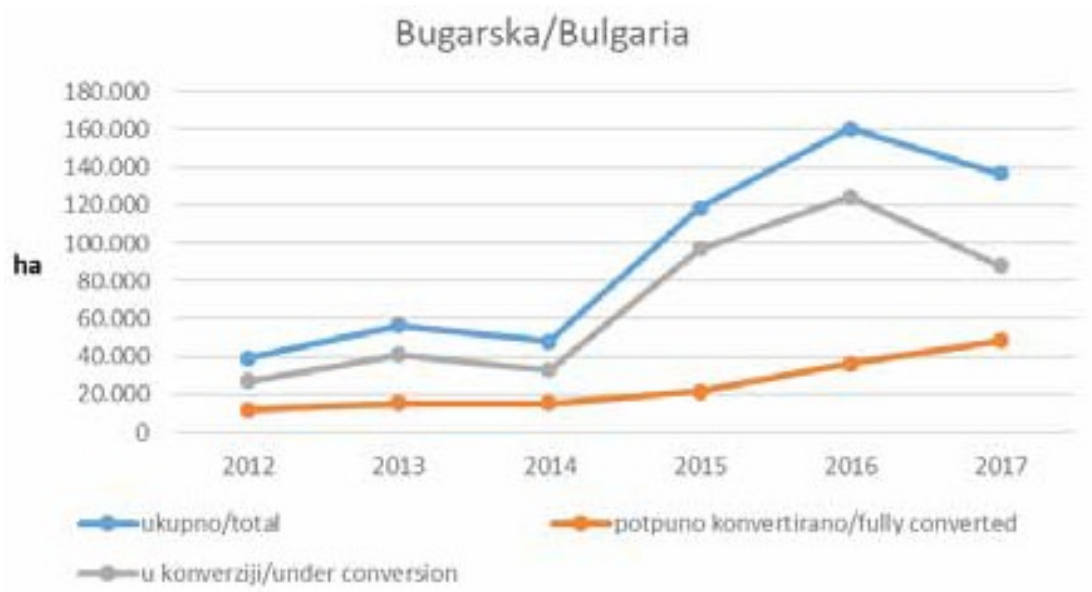

Grafikon 4. Površine u konverziji i potpuno konvertirane u ekološku poljoprivredu u Bugarskoj/ Graph 4. Areas under conversion and fully converted to organic farming in Bulgaria

Izvor: Izrada autora prema podatcima EUROSTAT-a/Source: Prepared by the author according to EUROSTAT data

U Hrvatskoj je obzirom na način korištenja najveći rast površina pod trajnim travnjacima i to za čak 434\% (grafikon 5). Mikuš i sur. (2019) smatraju kako je povećanje površina pod trajnim travnjacima pozitivno za okoliš, no negativno za ostvarivanje dodatne vrijednosti u hrvatskoj poljoprivredi. Također navode da je mogući razlog povećanja površina pod trajnim travnjacima i privlačan iznos potpora od 102 do 309,94 EUR/ha. Gugić i sur. (2017) pak navode kako je vjerojatni razlog tome manje zahtjevna implementacija ekološkog sustava gospodarenja na toj kategoriji poljoprivrednog zemljišta. 


\section{Hrvatska/Croatia}

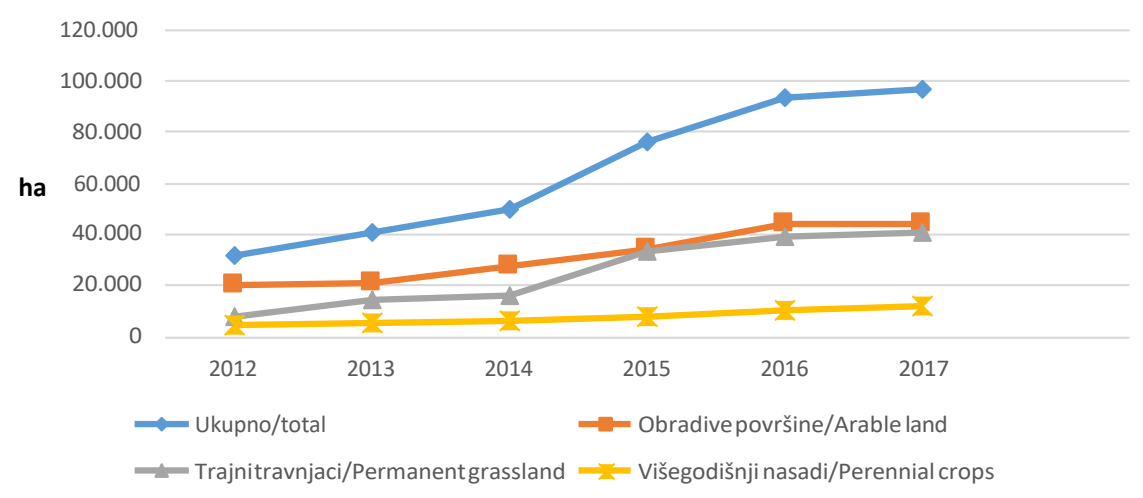

Grafikon 5. Površine pod ekološkom poljoprivredom u Hrvatskoj prema načinu korištenja/

Graph 5. Area under organic farming in Croatia according to the way of use

Izvor: Izrada autora prema podatcima EUROSTAT-a/Source: Prepared by the author according to EUROSTAT data

U Francuskoj je u promatranom razdoblju, kao i u Hrvatskoj, zabilježeno najveće povećanje površina pod trajnim travnjacima $(78,7 \%)$, slijede obradive površine $(68,8 \%)$ i višegodišnji nasadi $(31,9 \%)$ (grafikon 6). Premda površine pod ekološkom poljoprivredom rastu, količina proizvodnje nije dovoljna da zadovolji rastuće francusko tržište koje je sa 7 milijardi eura u 2016. godini (Barbier, 2017) naraslo na 9,7 milijardi eura u 2018. (Gouvernment.fr, 2019). Barbiere (2017) navodi kako je velik rast potražnje za ekološkim proizvodima potaknuo tamošnjeg ministra poljoprivrede na skorašnje ukidanje državne potpore ekološkim proizvođačima jer smatra da ekološki proizvodi više nisu tržišna niša te da je tržište to koje in treba poduprijeti.

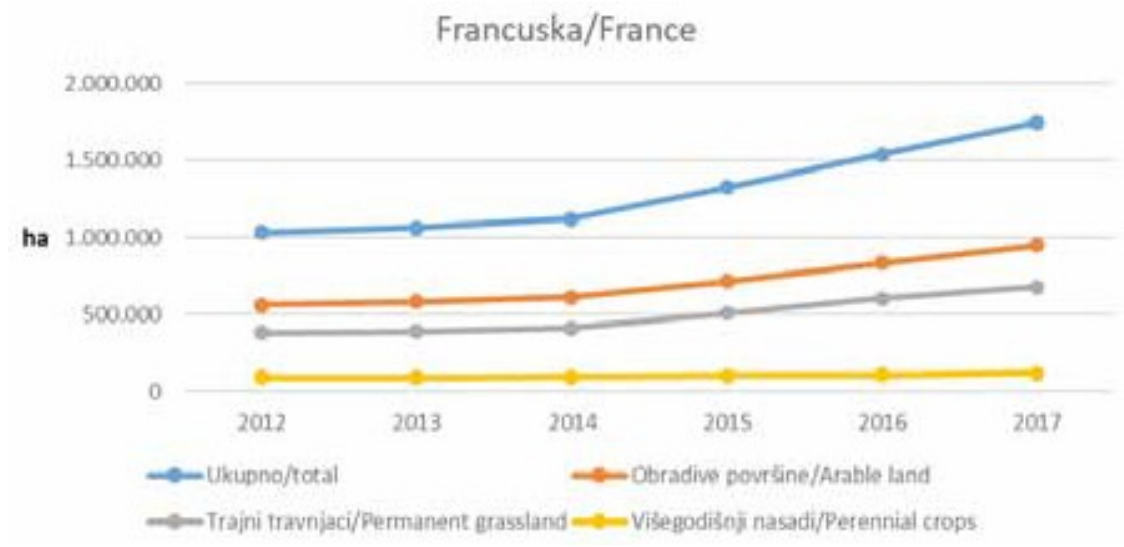

Grafi on 6. Površine pod ekološkom poljoprivredom u Francuskoj prema načinu korištenja/ Graph 6. Area under organic farming in France according to the way of use

Izvor: Izrada autora prema podatcima EUROSTAT-a/Source: Prepared by the author according to EUROSTAT data 
Način korištenja poljoprivrednih površina pod ekološkom poljoprivredom u Italiji razlikuje se od prosjeka EU 28 kao i od većine država članica (grafikon 7). U Italiji trajni nasadi u ekološkoj poljoprivredi zauzimaju 24,46\% ukupnih ekoloških površina u 2017. godini dok se taj postotak na razini EU 28 kreće oko 11\%. Velike površine pod trajnim nasadima u Italiji nalaze se na Siciliji, regiji koja je prednjačila u pretvorbi s konvencionalne na ekološku poljoprivredu još 1990-ih godina (Compagnoni, 2000). Trajni travnjaci zauzimaju 28,5\%, a obradive površine 47,03\% ukupnih ekoloških površina u Italiji.

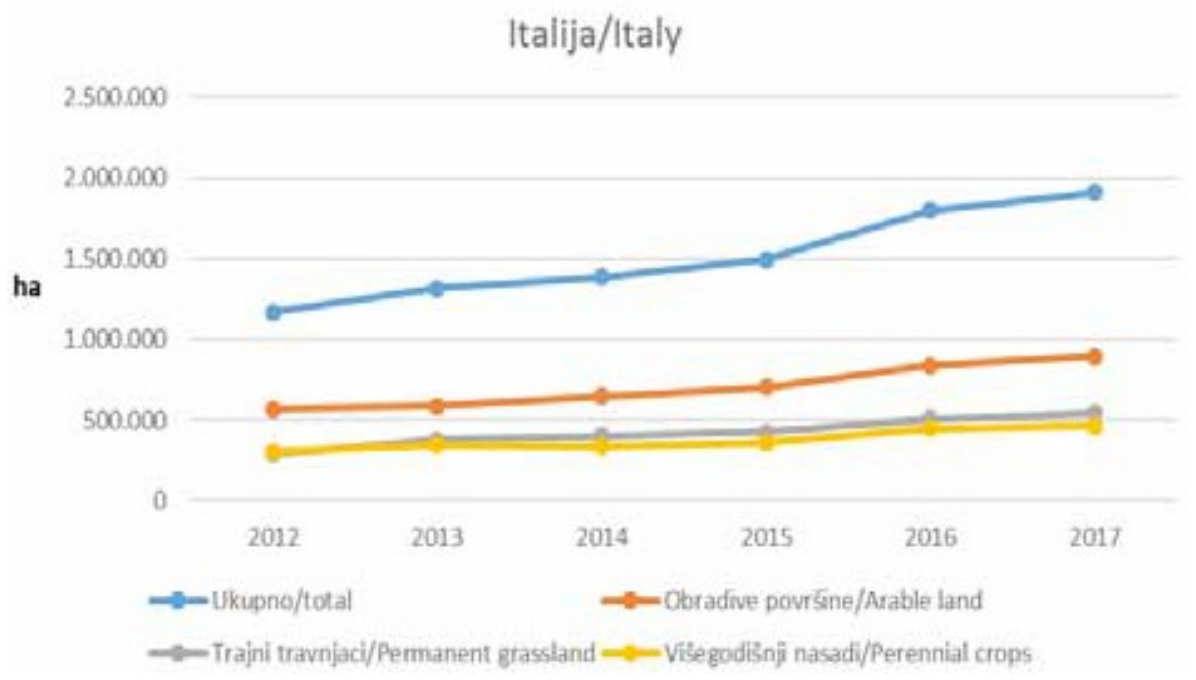

Grafikon 7. Površine pod ekološkom poljoprivredom u Italiji prema načinu korištenja/ Graph 7. Area under organic farming in Italy according to the way of use Izvor: Izrada autora prema podatcima EUROSTAT-a/Source: Prepared by the author according to EUROSTAT data

Drexler i Deszeny (2013) navode da su površine pod ekološkom poljoprivredom u Mađarskoj najviše rasle u razdoblju između 1996. i 2004. godine kada nastupa stagnacija koja traje sve do 2015. godine nakon čega dolazi do naglog rasta. U Mađarskoj najveću stopu rasta u razdoblju 2012.-2017. bilježe površine pod višegodišnjim nasadima (90,9 \%), no njihov je udio u 2017. godini još uvijek vrlo nizak (oko 5 \%) (grafikon 8). Udio trajnih travnjaka je najveći $(54,69 \%)$ no ti su travnjaci prema Drexler i Deszeny (2013) neiskorišteni jer je ekološki uzgoj stoke relativno beznačajan. Također navode kako se većina ekoloških proizvoda izvozi u Njemačku, Austriju, Nizozemsku i Švicarsku jer je tržište tim proizvodima u Mađarskoj relativno nerazvijeno. 


\section{Mađarska/Hungary}

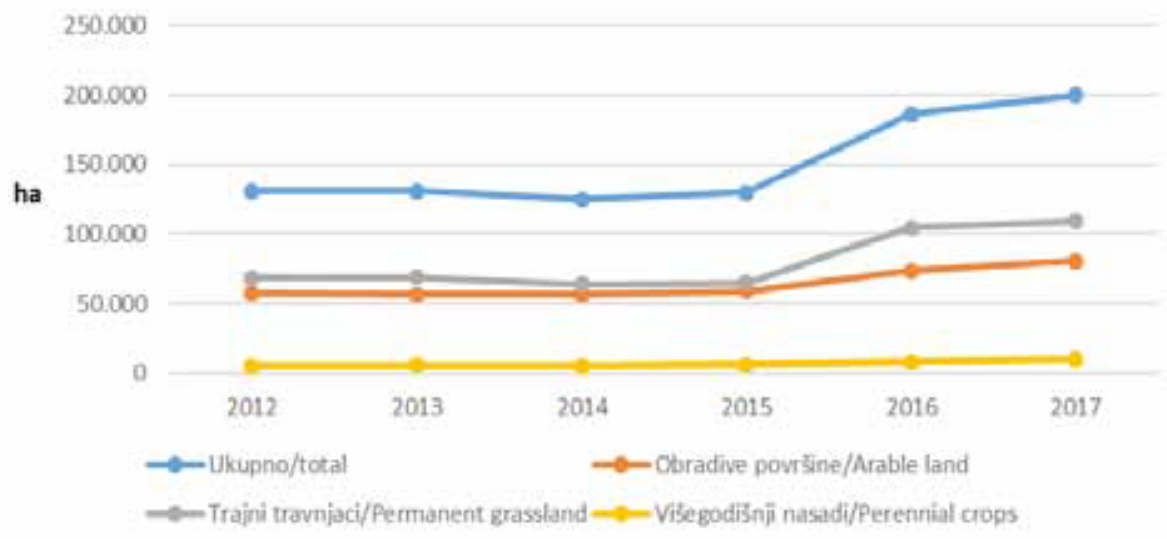

Grafi on 8. Površine pod ekološkom poljoprivredom u Mađarskoj prema načinu korištenja/ Graph 8. Area under organic farming in Hungary according to the way of use Izvor: Izrada autora prema podatcima EUROSTAT-a/Source: Prepared by the author according to EUROSTAT data

Struktura korištenja površina pod ekološkom poljoprivredom u Litvi također odudara od prosjeka EU 28. U 2017. godini su najzastupljenije obradive površine $(63,98 \%)$, slijede trajni travnjaci (33,55\%), dok su na začelju višegodišnji nasadi v vrlo niskim udjelom (2,47\%) (grafikon 9) koji se iz godine u godinu smanjuje (Pilipavičius i Grigaliūnas, 2014).

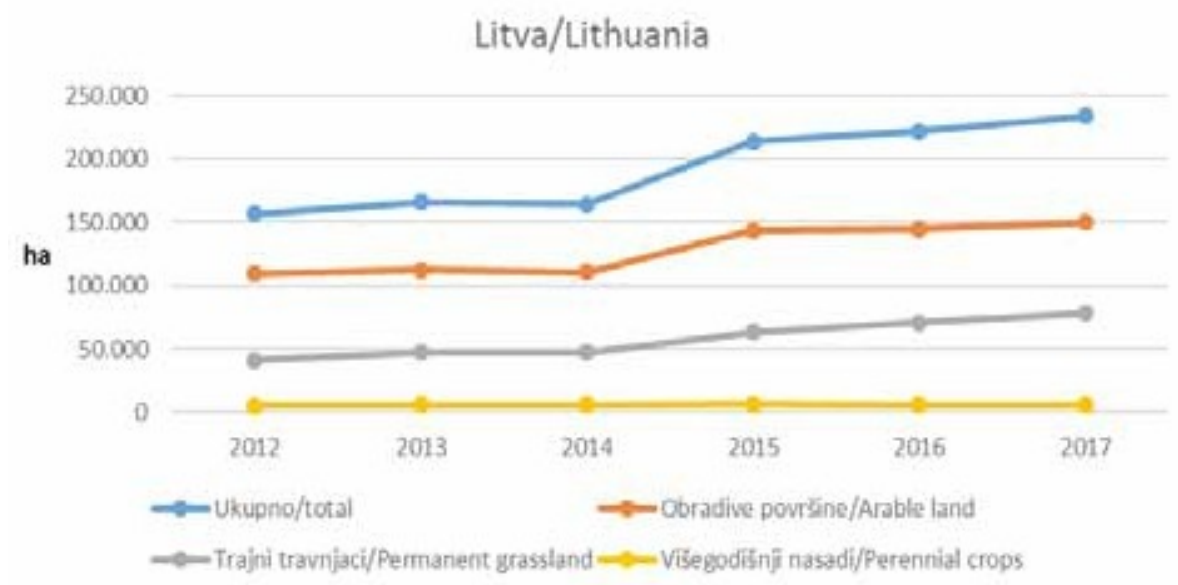

Grafikon 9. Površine pod ekološkom poljoprivredom u Litvi prema načinu korištenja/ Graph 9. Area under organic farming in Lithuania according to the way of use Izvor: Izrada autora prema podatcima EUROSTAT-a/Source: Prepared by the author according to EUROSTAT data 


\title{
Zaključak
}

Na razini EU 28 u razdoblju od 2012. do 2017. godine bilježi se povećanje pod ekološkom poljoprivredom za 25\%. Najveće povećanje površina u EU imaju Bugarska (249\%) i Hrvatska (203\%), a slijede: Francuska (69,21\%), Italija (63,49\%), Mađarska (52,89\%) i Litva $(49,57 \%)$. Obzirom na način korištenja u EU u 2017. godini ima podjednako obradivih površina $(44,5 \%)$ i trajnih travnjaka $(44,4 \%)$ dok višegodišnji nasadi zauzimaju $11,1 \%$ površina. U svim promatranim državama, osim Mađarske, obzirom na način korištenja prevladavaju obradive površine. U Mađarskoj najveći udio zauzimaju trajni travnjaci, dok je vrlo malo trajnih nasada $(4,99 \%)$ kao i u Litvi (2,47\%). Za razliku od te dvije države, u Italiji i Bugarskoj višegodišnji nasadi zauzimaju velikudio, $24,46 \%$, odnosno $22,31 \%$.

\section{Literatura}

Barbiere, C. (2017). URL: https://www.euractiv.com/section/agriculture-food/news/france-to-cut-support-for-booming-organic-farming/. (28.10.2019.)

Compagnoni, A., Pinton, R. Zanoli, R. (2000) Organic farming in Italy. Stiftung Ökologie \& Landbau (SÖL). Bad Dürkheim, Germany, 171-183.

Drexler, D. Dezsény, Z. (2013) Organic agriculture and research in Hungary, ISOFAR Newsletterr No 17, 3-8.

Gouvernment.fr (2019) URL: https://www.gouvernement.fr/en/french-organic-farming-in-better-shape-than-ever. (28.10.2019.)

Gugić, J., Grgić, I., Dobrić, B., Šuste, M., Džepina, M., Zrakić, M. (2017) Pregled stanja i perspektiva razvoja ekološke poljoprivrede u Republici Hrvatskoj. Glasnik zaštite bilja 44, 3, 20-30. https://doi.org/10.31727/gzb.40.3.2.

Jancsovszka-Puskas, P. (2015) Characteristics of the Bulgarian Organic Agriculture. Acta Tehnica Corviniensis - Bulletin of Engineering Tome VIII, No 4, 29-32.

Lernoud, J., Willer, H. (2019) Land use and key crops in organic agriculture 2017, Organic Agriculture Worldwide: Key results from the FiBL survey on organic agriculture worldwide. FIBL, Switzerland.

Mikuš, O., Ravlić, M., Hadelan, L., Jež Rogelj, M., Ljubaj, T. (2019) Uloga poljoprivredne politike u odnosu poljoprivrede i okoliša. U: Mioč, B., Širić, I., ur. Zbornik radova 54. hrvatskog i 14. međunarodnog simpozija agronoma. Zagreb: Agronomski fakultet Sveučilišta u Zagrebu, 143-147.

Ministarstvo poljoprivrede (2019) URL: https://poljoprivreda.gov.hr/istaknute-teme/poljoprivreda-173/poljoprivreda-175/ekoloska/upisnici-i-registri-208/208 (25.10.2019.)

Palšováa, L., Schwarczováa, L., Schwarcza, P., Bandlerováa, A. (2014) The support of implementation of organic farming in the Slovak Republic in the context of sustainable development, Procedia - Social and Behavioral Sciences, 110, $520-529$.

Pilipavičius, V., Grigaliūnas, A. (2014) Lithuanian Organic Agriculture in the Context of European Union, Organic Agriculture Towards Sustainability, (ed. V. Pilipavicius), DOI: $10.5772 / 58352$

Willer, H., Lernoud, J. (2019) The World of Organic Agriculture. Statistics and Emerging Trends. Research Institute of Organic Agriculture (FiBL), Frick and IFOAM Organics International, Bonn.

Willer, H., Schaack, D., Lernoud, J. (2019) Organic Farming and Market Development in Europe and the European Union. U: Willer, H. and Lernoud, J., ur. The World of Organic Agriculture: Statistics and Emerging Trends. Bonn: Research Institute of Organic Agriculture (FiBL), Frick and IFOAM Organics International, 217-247.

Zrakić, M., Jež Rogelj, M., Grgić, I. (2017) Organic agricultural production on family farms in Croatia. Agroecology and Sustainable Food Systems 41(6), 635-649. DOI: https://www.tandfonline.com/doi/full/10.1080/21683565.2017.1290731

Prispjelo/Received: 8.6.2020.

Prihvaćeno/Accepted: 19.6.2020.

Review paper

\section{Way of use of ecological area at EU level and in selected member states}

\begin{abstract}
Organic farming is a growing sector in the European Union (EU). The aim of the paper was to identify ways of using ecological surfaces at EU level and in selected Member Countries in the period 2012 to 2017. Ecological areas at the EU level increased by $25 \%$ in the observed period. The largest increase was recorded in Bulgaria (249\%) and Croatia (202\%), followed by France (69.21\%), Italy (63.49\%), Hungary (52.89\%) and Lithuania (49.57\%). Considering the use in the European Union in 2017, there is equally arable land (44.5\%) and permanent grassland (44.4\%), while perennial plantations cover $11.1 \%$ of the area. When monitoring the movements of individual land use in the period from 2013 to 2017, the highest growth recorded arable land (29\%), followed by permanent grassland (22\%) and perennial plants (19\%).

Keywords: $E U$, land use, organic farming
\end{abstract}

